\title{
Reformation of casein particles from alkaline-disrupted casein micelles
}

\author{
Thom Huppertz ${ }^{1}$ t, $^{*}$ Betsy Vaia ${ }^{1,2}$ and Mary A Smiddy ${ }^{1}$ \\ ${ }^{1}$ Department of Food and Nutritional Sciences, University College Cork, Cork, Ireland \\ ${ }^{2}$ Hochschule Wadenswil, Wadenswil, Switzerland
}

Received 26 September 2006 and accepted for publication 29 August 2007

\begin{abstract}
In this study, the properties of casein particles reformed from alkaline disrupted casein micelles were studied. For this purpose, micelles were disrupted completely by increasing milk $\mathrm{pH}$ to $10 \cdot 0$, and subsequently reformed by decreasing milk $\mathrm{pH}$ to $6 \cdot 6$. Reformed casein particles were smaller than native micelles and had a slightly lower zeta-potential. Levels of ionic and serum calcium, as well as rennet coagulation time did not differ between milk containing native micelles or reformed casein particles. Ethanol stability and heat stability, $>\mathrm{pH} 7 \cdot 0$, were lower for reformed casein particles than native micelles. Differences in heat stability, ethanol stability and zeta-potential can be explained in terms of the influence of increased concentrations of sodium and chloride ions in milk containing reformed casein particles. Hence, these results indicate that, if performed in a controlled manner, casein particles with properties closely similar to those of native micelles can be reformed from alkaline disrupted casein micelles.
\end{abstract}

Keywords: Milk, casein micelle, alkaline disruption, solvent quality.

Casein micelles, the sterically-stabilised association colloids in bovine milk, disintegrate when the solvent quality of the milk serum increases. Solvent-mediated disintegration of casein micelles occurs because interactions of the hydrophobic domains of the protein with the solvent become thermodynamically favourable, and can be induced by adding $>3.5 \mathrm{~mol} \mathrm{~L}^{-1}$ urea to milk (Holt, 1998; De Kruif \& Holt, 2003), addition of $>30 \%$ ethanol to milk followed by heating to $>60{ }^{\circ} \mathrm{C}\left(\mathrm{O}^{\prime}\right.$ Connell et al. 2001a, b) or increasing milk pH to $>9 \cdot 0$ (Van Dijk, 1992; Vaia et al. 2006). Such disintegration is believed to yield individual nanoclusters (Vaia et al. 2006), which are the 'building blocks' of casein micelles (De Kruif \& Holt, 2003; Holt et al. 2003). The nanoclusters consist of an amorphous core of calcium phosphate, often referred to as micellar calcium phosphate (MPC), surrounded by a shell of caseins though calcium-phosphate ion pairs involving the centres of phosphorylation of $\alpha_{\mathrm{s}^{-}}, \alpha_{\mathrm{s} 2^{-}}$and $\beta$-casein (Holt et al. 2003; Holt, 2004).

Semo et al. (2007) recently reported that artificial casein micelles formed from sodium caseinate can be effectively used for nano-encapsulation and stabilization of hydrophobic nutraceuticals, e.g., vitamin D2. Likewise,

*For correspondence; e-mail: thom.huppertz@nizo.nl tPresent address: NIZO food research, Ede, The Netherlands micelles reformed following solvent-mediated disruption could also be utilized as carriers for nutraceuticals. For the successful application of reformed micelles for this purpose, it is important that the reformed micelles have properties comparable to those of native casein micelles, particularly in terms of colloidal stability, so as not to limit their application in dairy products. O'Connell et al. (2003) studied the properties of casein particles reformed from milk which was heated in the presence of ethanol. Such reformed casein particles were considerably larger than native casein micelles and also differed considerably in terms of the colloidal stability of the micelles against heat or ethanol ( $\mathrm{O}^{\prime}$ Connell et al. 2003). Casein micelles reformed after urea-induced disruption are smaller than native micelles, but resemble native micelles quite closely in terms of colloidal stability (McGann \& Fox, 1974); however, the need to add and remove large quantities of urea to induce micellar disruption and reformation limits practical applications of this approach. Due to the considerably smaller amounts of additives required for the reformation of alkaline disrupted casein micelles, this process may present a more viable alternative. Properties of casein particles reformed from alkaline disrupted casein micelles, however, have not been examined to date and were the subject of investigation in the studies reported in this article. Reformed casein particles were created by consecutive solvent-mediated disintegration 
and reassociation of casein micelles, induced by increasing milk $\mathrm{pH}$ to $10 \cdot 0$ and subsequently reducing it to $\mathrm{pH} 6 \cdot 6$.

\section{Materials and Methods}

\section{Sample preparation}

Low-heat skim milk powder (Irish Dairy Board, Dublin, Ireland) was reconstituted in demineralised water, containing $0.5 \mathrm{~g} \mathrm{~L}^{-1}$ sodium azide, at a level of $90 \mathrm{~g} \mathrm{~L}^{-1}$. Alkaline disruption of casein micelles was induced by the dropwise addition to $200 \mathrm{ml}$ milk, of $1 \mathrm{M}-\mathrm{NaOH}$ to $\mathrm{pH} 10.0$ at $20^{\circ} \mathrm{C}$, with simultaneous stirring. After $60 \mathrm{~min}$ holding at room temperature at $\mathrm{pH} 10 \cdot 0$, milk $\mathrm{pH}$ was returned to 6.6 by the dropwise addition of $1 \mathrm{M}-\mathrm{HCl}$ at a rate of $0 \cdot 1 \mathrm{ml} \mathrm{min}{ }^{-1}$ with simultaneous stirring; approximately $2.5 \mathrm{ml} 1 \mathrm{M}-\mathrm{NaOH}$ were required to increase milk $\mathrm{pH}$ to 10.0 and an equivalent volume of $1 \mathrm{M}-\mathrm{HCl}$ was required to subsequently reduce $\mathrm{pH}$ to $6 \cdot 6$. Throughout disruption and reformation, the turbidity of milk was determined at $600 \mathrm{~nm}$ using a $1 \mathrm{~mm}$ path-length cuvette, and normalised according to the turbidity values of untreated milk $(=1 \cdot 00)$ and milk serum $(=0 \cdot 00)$ as outlined by Vaia et al. (2006). For separate samples, an equivoluminar mixture of $1 \mathrm{M}$ $\mathrm{HCl}$ and $1 \mathrm{M}-\mathrm{NaOH}$ or a solution of $0.5 \mathrm{~mol} \mathrm{~L}^{-1} \mathrm{NaCl}$ was added to milk at a level of $5 \mathrm{ml} 100 \mathrm{ml}^{-1}$. Three independent replicate samples were prepared for all milks.

\section{Analytical methods}

Casein micelle size and zeta potential were determined by photon correlation spectroscopy and laser-Doppler electrophoresis, respectively, as outlined by Huppertz \& Fox (2006). The stability of milk against heat-induced coagulation at $140^{\circ} \mathrm{C}$ was determined as a function of $\mathrm{pH}$ as described by Huppertz et al. (2004). The stability of milk against ethanol-induced flocculation was determined at $\mathrm{pH} 6 \cdot 0,6 \cdot 5$ and $7 \cdot 0$, as described by Huppertz et al. (2004). The rennet coagulation time of milk was determined as described by Zobrist et al. (2005). The concentration of ionic calcium was determined using an ion selective electrode (Vaia et al. 2006). The concentration of total calcium in the milk serum was determined by atomic absorption spectroscopy, as outlined by Vaia et al. (2006).

\section{Statistical analysis}

The significance of differences in physicochemical properties between native casein micelles and casein particles reformed from alkaline disrupted casein micelles were analysed using a t-test at a $95 \%$ confidence level.

\section{Results and Discussion}

Increasing milk $\mathrm{pH}$ to 10.0 reduced milk turbidity to a value close to that of milk serum (Fig. 1), indicating

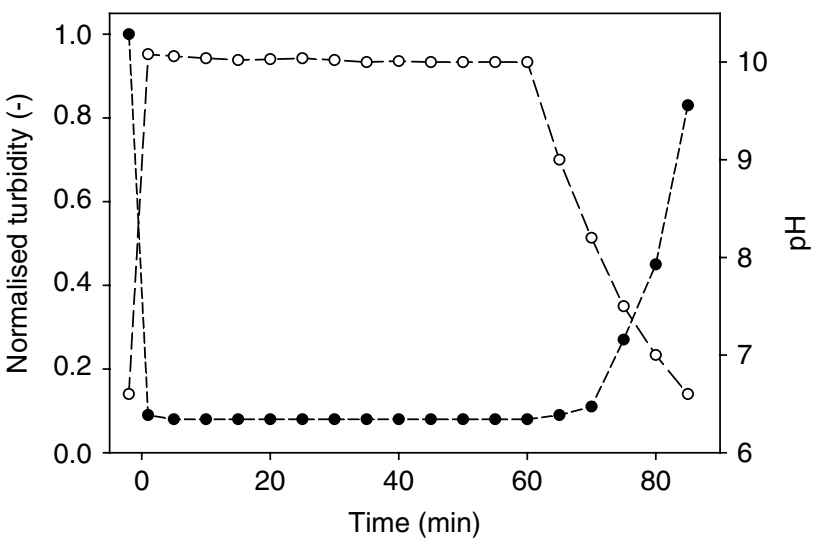

Fig. 1. Normalised turbidity $(\bullet)$ and $\mathrm{pH}(\bigcirc)$ of skim bovine milk on addition of $1 \mathrm{M}-\mathrm{NaOH}$ to increase milk $\mathrm{pH}$ to 10 ( $\mathrm{t}=0 \mathrm{~min}$ ), followed by holding for $60 \mathrm{~min}$ and subsequent addition of $1 \mathrm{M}$ -

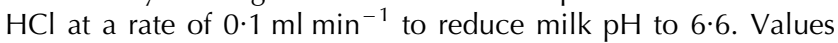
are means of data on three individual milk samples. The coefficient of variation was $<5 \%$ for all data points.

complete disintegration of casein micelles, probably into its constituent nanoclusters. Similar observations were reported by Vaia et al. (2006), who suggested that alkaline disruption of casein micelles is primarily due to increased solvent quality of milk serum at alkaline $\mathrm{pH}$, as a result of significant reductions in the concentration of calcium and phosphate in the milk serum at high $\mathrm{pH}$. Subsequently readjusting milk $\mathrm{pH}$ to 6.6 increased turbidity, to a value close to that of untreated milk ( $\sim 0 \cdot 83$; Fig. 1$)$, indicating the reformation of casein particles. Preliminary experiments had shown that the rate addition of $1 \mathrm{M}-\mathrm{HCl}$ $\left(0 \cdot 02-0.5 \mathrm{ml} \mathrm{min}^{-1}\right)$ had no significant effect on the results so only $0 \cdot 1 \mathrm{ml} \mathrm{min}^{-1}$ was selected for further experiments. Addition of $1 \mathrm{M}-\mathrm{HCl}$ at a rate $>0.5 \mathrm{ml} \mathrm{min}{ }^{-1}$ resulted in some micellar flocculation in the samples, strongly suggesting that the reformation processes needs to be carried out in a gradual and controlled manner.

Concentrations of serum and ionic calcium did not differ significantly between control milk and milk which was first adjusted to $\mathrm{pH} 10 \cdot 0$ and subsequently readjusted to pH 6.6 (Table 1), indicating that the extensive reductions $(>95 \%)$ in these parameters which occur on increasing milk pH (Vaia et al. 2006) are fully and rapidly reversible. This suggests that the increase in solvent quality induced by increasing milk pH (Vaia et al. 2006) is reversible on subsequent readjustment of $\mathrm{pH}$ to $6 \cdot 6$. The reversal of solvent quality is probably the primary reason for the reformation of casein particles from alkaline-disrupted casein micelles. The physicochemical properties of the casein particles were the subject of investigation in the following studies.

Casein micelle size was significantly $(P<0 \cdot 05)$ lower for reformed casein particles compared with native casein micelles (Table 1); McGann \& Fox (1974) reported similar observations for casein particles reformed after urea-induced disruption of casein micelles. No significant 
Table 1. Physicochemical properties of native casein micelles and casein particles formed by first disrupting casein micelles by increasing milk $\mathrm{pH}$ to 10.0 and subsequent reforming casein particles by reducing milk $\mathrm{pH}$ to $6 \cdot 6$. Values are means of data from experiments on three individual milk samples, \pm standard deviation

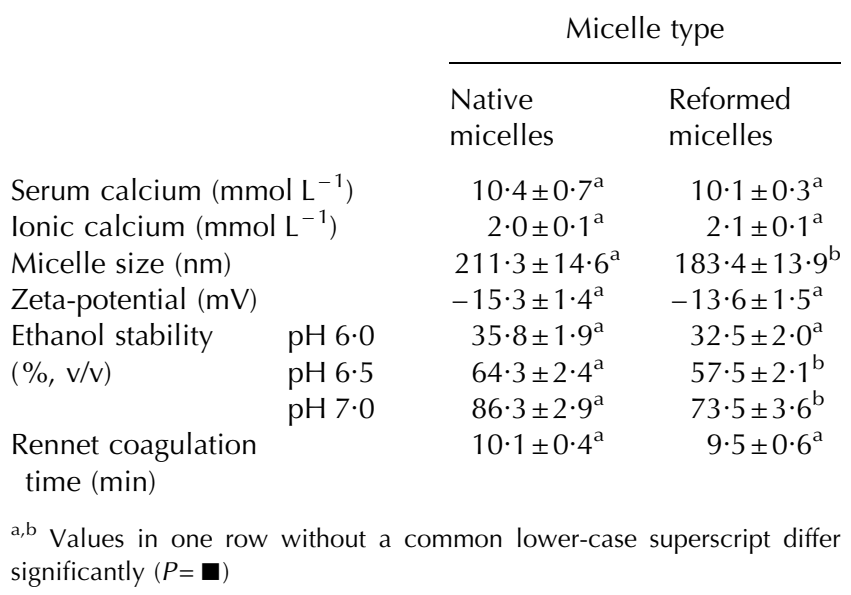

difference in zeta potential between native casein micelles and reformed casein particles was apparent (Table 1). At $\mathrm{pH} 6.50$ and 7.00, but not at $\mathrm{pH} 6 \cdot 00$, the ethanol stability of reformed micellar particles was significantly lower than that for native particles, whereas no significant difference in rennet coagulation time was apparent between control milk and milk containing reformed micelles (Table 1). The pH-HCT profile for milk containing native or reformed casein micelles was similar in the $\mathrm{pH}$ range $6 \cdot 3-7 \cdot 0$, with a maximum at $\mathrm{pH} 6 \cdot 8$. However, in control milk, HCT increased with increasing $\mathrm{pH}>7 \cdot 0$, whereas no such recovery was observed in milk containing reformed casein particles (Fig. 2). Overall, it is clear that reformed casein particles closely resemble native casein micelles, in terms of physicochemical properties and colloidal stability. Small differences in physicochemical properties that existed between milks containing native micelles or reformed casein particles may indicate that the micelles do not reform in exactly the same way; however, it should also be considered that the addition of equal volumes of $\mathrm{NaOH}$ and $\mathrm{HCl}$, effectively equals the addition of a $\mathrm{NaCl}$ solution to milk, which is known to influence physicochemical properties of the micelles.

Differences between the heat stability of native micelles and reformed casein particles may be ascribed to the influence of the additives, i.e., $1 \mathrm{M}-\mathrm{HCl}$ and $1 \mathrm{M}-\mathrm{NaOH}$, rather than structural differences between native casein micelles and reformed casein particles, since the addition of an equivalent volume of $a$, neutral, mixture of $\mathrm{NaOH}$ and $\mathrm{HCl}$ or an equivalent amount of $0.5 \mathrm{M}-\mathrm{NaCl}$ induced the same changes in heat stability as increasing and subsequently decreasing $\mathrm{pH}$ (Fig. 2). The increased levels of sodium and chloride ions may also be responsible for the lower ethanol stability and higher zeta-potential of

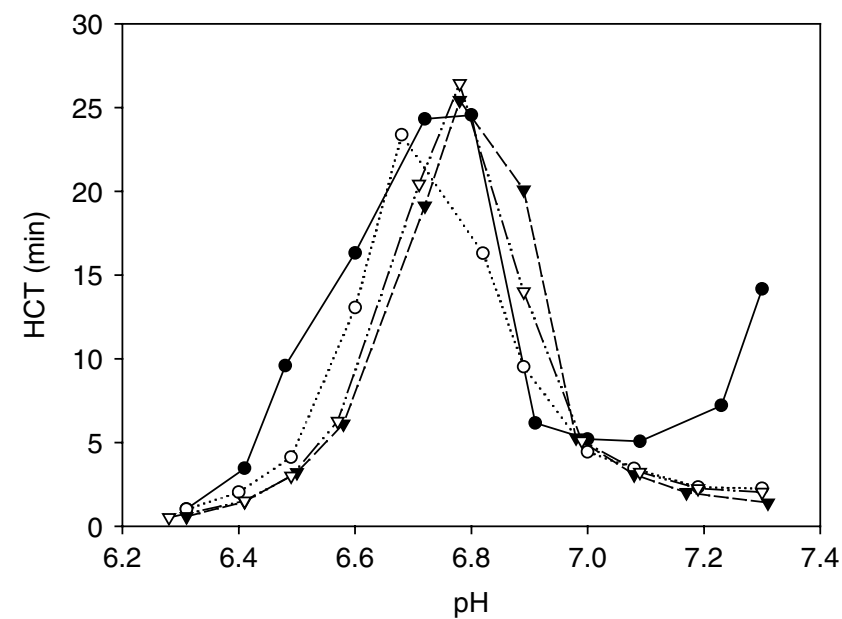

Fig. 2. $\mathrm{pH}$-heat coagulation time profile of control skim bovine milk (๑), skim bovine milk which was adjusted to $\mathrm{pH} 10 \cdot 0$ and subsequently readjusted to $\mathrm{pH} 6.6(\bigcirc)$, skim milk to which a solution containing $0.5 \mathrm{~mol} \mathrm{~L}^{-1} \mathrm{HCl}$ and $0.5 \mathrm{~mol} \mathrm{~L}^{-1} \mathrm{NaOH}$ was added at a level of $5 \mathrm{ml} 100 \mathrm{ml}^{-1}(\boldsymbol{\nabla})$ or skim milk to which $0.5 \mathrm{~mol} \mathrm{~L}^{-1} \mathrm{NaCl}$ was added at $5 \mathrm{ml} 100 \mathrm{ml}^{-1}(\nabla)$.

milk containing reformed casein particles (Table 1), as addition of sodium chloride to milk reduces ethanol stability (Horne \& Parker, 1987; Huppertz \& Fox, 2006) and zeta-potential (Dalgleish, 1984; Huppertz \& Fox, 2006). However, differences in micelle size and turbidity (Table 1), which are closely related owing to the fact that casein micelles are the primary light scattering particles in skim milk, cannot be explained with the current knowledge of $\mathrm{NaCl}$ on physicochemical properties of milk and suggest that micelles do not reform to exactly their native form.

From the differences in micelle size and turbidity, it can be estimated that the total amount of micellar material is slightly higher in reformed samples than in native samples. From light scattering theory, it follows that for the turbidity, $\tau$ :

$\tau \propto M \cdot C$

Where $M$ and $C$ are the mass and total concentration of light scattering particles in the sample (for a more detailed description see Huppertz et al. 2007). Since M scales to the third power of particle diameter, $d$, it follows that

$\tau \propto C \cdot d^{3}$

Solving equation 2 for the turbidity (Fig. 1) and particle size (Fig. 2) data indicates that $\mathrm{C}_{\text {reformed }} / \mathrm{C}_{\text {native }}=$ $1 \cdot 09 \pm 0 \cdot 04$. Hence, levels of non-micellar casein are expected to be lower in samples containing reformed micelles than in those containing native micelles, which may further contribute to differences in physicochemical properties between samples.

Overall, the physicochemical properties of casein particles reformed from alkaline disrupted casein micelles 
closely resembled those of native casein micelles, similar to those reformed after urea-induced disruption of casein micelles (McGann \& Fox, 1974). This suggests that if reversal of the increase in solvent quality induced by increasing milk $\mathrm{pH}$ is carried out in a gentle and controlled manner, the disintegration of casein micelles is largely reversible. Hence, it is apparent that casein micelles can undergo reversible association and dissociation reactions on changes in solvent quality which may be utilised in the selective incorporation of nutraceutical compounds in casein micelles.

\section{References}

De Kruif CG \& Holt C 2003 Casein micelle structure, functions and interactions. In PF Fox, PLH McSweeney Eds.: Advanced Dairy Chemistry, Vol. 1: Proteins, 3rd edn. pp. 233-276. Kluwer Academic/ Plenum Publishers, New York, NY

Dalgleish DG 1984 Measurement of electrophoretic mobilities and zetapotentials of particles from milk using laser Doppler electrophoresis. Journal of Dairy Research $\mathbf{5 4}$ 425-438

Holt C 1998 Casein micelle substructure and calcium phosphate interactions studied by sephacryl column chromatography. Journal of Dairy Science 81 2994-3003

Holt C 2004 An equilibrium thermodynamic model of the sequestration of calcium phosphate by casein micelles and its application to the partition of salts in milk. European Biophysics Journal 33 421434

Holt C, De Kruif CG, Tuinier R \& Timmins PA 2003 Substructure of bovine casein micelles by small-angle $\mathrm{X}$-ray and neutron scattering. Colloids and Surfaces A 213 275-284
Horne DS \& Parker TG 1983 Factors affecting the ethanol stability of bovine skim-milk. VI. Effect of concentration. Journal of Dairy Research 50 425-432

Huppertz T \& Fox PF 2006 Effect of $\mathrm{NaCl}$ on some physico-chemical properties of bovine milk. International Dairy Journal 16 1142-1148

Huppertz T, Grosman S, Fox PF \& Kelly AL 2004 Heat and ethanol stabilities of high pressure-treated bovine milk. International Dairy Journal 14 125-133

Huppertz T, Smiddy MA \& De Kruif CG 2007 Biocompatible microgelparticles from cross-linked casein micelles. Biomacromolecules 8 1300-1305

McGann TCA \& Fox PF 1974 Physico-chemical properties of casein micelles reformed from urea-treated milk. Journal of Dairy Research 41 45-53

O'Connell JE, Kelly AL, Auty MAE, Fox PF \& De Kruif KG 2001a Ethanoldependent heat-induced dissociation of casein micelles. Journal of Agricultural and Food Chemistry 49 4420-4423

O'Connell JE, Kelly AL, Fox PF \& De Kruif KG 2001b Mechanism for ethanol-dependent heat-induced dissociation of casein micelles. Journal of Agricultural and Food Chemistry 49 4424-4428

O'Connell JE, Steinle, S, Reiter F, Auty MAE, Kelly AL \& Fox PF 2003 Properties of casein micelles reformed from heated mixtures of milk and ethanol. Colloids and Surfaces A 213 265-273

Semo E, Kesselman, E, Danino D \& Livney YD 2007 Casein micelle as a natural nano-capsular vehicle for nutraceuticals. Food Hydrocolloids 21 936-942

Van Dijk HJM 1992 The properties of casein micelles. 6. Behaviour above $\mathrm{pH}$ 9, and implications for the micelle model. Netherlands Milk and Dairy Journal 46 101-113

Vaia B, Smiddy MA, Kelly AL \& Huppertz T 2006 Solvent-mediated disruption of casein micelles at alkaline $\mathrm{pH}$. Journal of Agricultural and Food Chemistry 54 8288-8293

Zobrist MR, Huppertz T, Uniacke T, Fox PF \& Kelly AL 2005 Highpressure-induced changes in the rennet coagulation properties of bovine milk. International Dairy Journal 15 655-662 